\title{
Spatial variation of soil quality indicators as a function of land use and topography
}

\section{Kiani, Mina}

2020-12

Kiani , M , Hernandez-Ramirez , G \& Quideau , S A M 2020 , ' Spatial variation of soil quality indicators as a function of land use and topography ', Canadian Journal of Soil Science, pÿvol. 100 , no. 4 , pp. 463478 . https://doi.org/10.1139/cjss-2019-0163

http://hdl.handle.net/10138/324090

https://doi.org/10.1139/cjss-2019-0163

cc_by_nc_sa

acceptedVersion

Downloaded from Helda, University of Helsinki institutional repository.

This is an electronic reprint of the original article.

This reprint may differ from the original in pagination and typographic detail.

Please cite the original version. 


\title{
Spatial Variation of Soil Quality Indicators as a Function of Land-use and Topography
}

\author{
Mina Kiani ${ }^{1}$ \\ Guillermo Hernandez-Ramirez ${ }^{2 *}$ \\ Sylvie A. M. Quideau ${ }^{2}$ \\ ${ }^{1}$ Department of Agricultural Sciences, University of Helsinki, P.O. Box 27, FI-00014 Helsinki, \\ Finland \\ ${ }^{2}$ Department of Renewable Resources, University of Alberta, 442 Earth Sciences Building, \\ Edmonton, Alberta, T6G 2E3, Canada
}

*Corresponding author: ghernand@ualberta.ca 


\begin{abstract}
Soil quality (SQ) indicators such as plant available water (PAW), organic carbon (SOC), and microbial biomass carbon $(\mathrm{MBC})$ can reveal agroecological functions; however, their spatial variabilities across contrasting land uses need to be better understood. This study examined the spatial variation of these key SQ indicators as a function of two land-use systems and using topography covariates. We sampled a total of 116 point-locations in a native grassland (NG) site and an irrigated cultivated (IC) site located near Brooks, Alberta. Compared to NG, cultivation altered soil pore-size distribution by sharply reducing macroporosity by $25 \%$. However, conditions in the IC soil supported greater accrual of microbial growth (MBC of 601 vs. 812 nmol Phospholipid fatty acids $\mathrm{g}^{-1}$ soil) probably due to more availability of water and nutrients. Focusing on the effects of topography on SQ indicators, terrain elevation (by light detection and ranging, LiDAR) and estimated depth-to-water were found to be key controllers of SQ at the two land-use systems. Also, there were gradual increases in both SOC and MBC where estimated water table was deeper, and higher SOC also associated with lower elevation. A comparison of ordinary kriging $(\mathrm{OK})$ and cokriging (coK) geostatistical mapping indicated that the coK method performed better as demonstrated by improvements in the accuracies of spatial estimations of PAW, SOC concentration, and $\mathrm{MBC}$. Thus, implementing coK using the aforementioned topography covariates enhances the capability for predictive mapping of SQ, which is particularly useful when spatial data for key SQ indicators are sparse and challenging to measure.
\end{abstract}

\footnotetext{
Keywords: cokriging; depth-to-water table; geostatistics; grassland; microbial community composition; topography
} 


\section{Introduction}

Land-use changes has been shown to impact the soil properties at the field scale (Hebb et al., 2017; Burst et al., 2020). Grasslands compared to croplands reported to have a welldeveloped hierarchical soil structure derived from extensive root growth of diverse perennial plants combined with low soil disturbance (Elliot, 1986; Hebb et al., 2017). However, inadequate grassland grazing may decrease soil fertility and productivity, whereas balanced nutrient management may sustain it (Chantigny, 2003; Burst et al., 2020). Similarly, changes in soil physical and chemical properties can affect the soil microbial community (Juma, 1994) across different land uses. Geisseler et al. (2016) reported higher gram-negative bacteria in natural grassland, and higher gram-positive bacteria in cropland. This interaction among different soil properties highlights the need for identifying several soil quality (SQ) indicators that may provide robust metrics of soil quality in contrasting land-uses. New information on responses of soil quality indicators to land use will play a vital role in preserving soil functions and improving land management and stewardship practices.

In addition to these land-use effects, topography is another soil-forming factor which dominantly affects soil properties at local scales (Jenny, 1941) through regulating soil hydrological regimes and controlling the gravity-driven soil movements (Speight, 1980; Li and McCarty, 2019). Accordingly, topography has been identified as one of the important sources of the heterogeneity of soil properties (Zhao et al., 2015; Burst et al., 2020). Wang et al. (2009) found that SOC and soil total nitrogen (STN) varied with topography in terms of slope and elevation. At lower landscape positions, soils are better supplied with water and nutrient-richer than on slopes and uplands (Hook and Burke, 2000). Likewise, it has been also reported that the depth-to-water-table index (DTW) can capture soil properties, such as the soil moisture regime, 
which are closely influenced by the water table (Oltean et al., 2016). Consequently, applications of topographic information for mapping spatial patterns of soil properties would improve the prediction accuracy and benefit the understanding of the mechanisms underlying the land-use impacts on soil properties.

Heterogeneity in soil properties across the landscape can represent a management challenge to producers and policymakers, in particular in fields where land-use changes commonly occur (Robertson et al., 1993; Nyamadzawo et al., 2008). Compared to uniform land management, information on spatial pattern of soil properties that are linked to relevant ecosystem functions can greatly improve land management practices including the identification of fertility management zones (Qiu et al., 2016). Therefore, there is a need for a more comprehensive understanding of the spatial structure of soil properties across competing land-use types (e.g., native grassland versus cultivated land). Different geostatistical methods have been applied to interpolate soil properties from sparse sampling points into continuous surfaces by modeling the spatial correlation with minimum variance (Cambardella et al., 1994; Hengl et al., 2004; Wang et al., 2009; Yang et al., 2016). Ordinary kriging (OK) uses weighted averages to estimate unsampled locations as a linear combination of statistically-neighboring observations (Mirzaee et al., 2016; Wang et al., 2013). When the spatial distribution of a secondary variate (e.g., a terrain covariate such as elevation) has been sampled more intensely than the primary variate, the cokriging (coK) method can be implemented (Davis, 1986; Chen et al., 2016; Yang et al., 2016). Incorporating terrain co-variables into interpolation procedures may provide an opportunity to obtain higher prediction accuracy while using the existing data of the primary variate. Moreover, if the primary variate is difficult or expensive to measure, coK can greatly improve interpolation estimates without the need for more intense measurements of the primary variate (Wang et al., 2013). The advantage of coK with 
different auxiliary variables has been reported with a focus on soil attributes (Wang et al., 2013; Ceddia et al., 2015; Chen et al., 2016).

More precise maps of the spatial variability of soil attributes in native prairie and cultivated lands may facilitate the strategic implementation of best management practices, which can lead to sustainable production systems embedded in multifunctional landscapes (Knotters et al., 1995). Aligned with previous studies, we initially hypothesized that: i) the selected soil quality indicators are significantly affected by land-use type and topography attributes, and ii) the implementation of topographic variables with the coK mapping technique enhances prediction of spatial distribution of SQ indicators. To test our hypotheses, we: i) determined the comparative effects of two common land-use systems (native grassland and cultivated land) on functional SQ indicators (i.e., PAW, SOC concentration, and MBC) and identified topography attributes that may best enable robust spatial prediction of the SQ status, and ii) interpolated and interpreted the spatial variabilities of these key SQ indicators from point measurements to field landscapes by extracting their spatial patterns while using and comparing ordinary kriging and coK geostatistical methods. 


\section{Materials and Methods}

\section{Study sites}

This study was conducted at two sites: a native grassland (NG; north-west corner: $50^{\circ} 53^{\prime}$ $54.4^{\prime \prime} \mathrm{N}, 111^{\circ} 57^{\prime} 40.2^{\prime \prime} \mathrm{W}$ ), and an irrigated cultivated (IC) land (north-west corner: $50^{\circ} 54^{\prime} 26.5^{\prime \prime}$ $\mathrm{N}, 111^{\circ} 58^{\prime} 41.1^{\prime \prime}$ W) located at the University of Alberta Mattheis Research Ranch within the dry, mixed-grass prairie natural sub-region of Alberta, Canada. The climate is continental, sub-humid, characterized by long, cold winters and short summers (Mollard et al., 2014). Mean annual precipitation and temperature are $354 \mathrm{~mm}$ and $4.2^{\circ} \mathrm{C}$, respectively (Hewins et al., 2016). Soil at both sites was classified as a Rego Brown Chernozem based on the Agricultural Region of Alberta Soil Inventory Database (AGRASID, 2015), and had a loamy sand texture. The particle size analysis followed the hydrometer method. The granulometric distribution for the native grassland soil was sand (2000-50 $\mu \mathrm{m}$ size diameter) 865 , silt $(50-2 \mu \mathrm{m}) 75$, and clay $(<2 \mu \mathrm{m}) 60 \mathrm{~g} \mathrm{~kg}^{-1}$ soil. For the IC land soil, the distribution was sand 831, silt 101, and clay $68 \mathrm{~g} \mathrm{~kg}^{-1}$ soil.

The native grassland (NG) was dominated by crested wheat grass (Gropyron cristatum), smooth brome grass (Bromus inermis), and Kentucky blue grass (Poa pratensis). This NG site also had various native species present such as Poa sandbergii, Stipa comate, Carex praticola, Equisetum hyemale, Artemesia frigida, Artemesia ludoviniaca, Heterotheca villosa, and Achillea millefolium. The land is currently used as cattle ranch on a rotational grazing basis for approximately six months each year, beginning in early May. The cultivated land (IC) site is irrigated by a center pivot system and planted with annual crops such as wheat and oat grown under conventional tillage practices for at least two decades. This site was seeded in spring 2014 to introduce pasture for grazing (one year prior to soil sample collection). The dominant plant 
species in this recently established pasture were alfalfa, red clover, Kentucky blue grass, and crested wheat grass.

\section{Nested cyclic sampling design}

All field samples were collected on June 6 and 7, 2015, at both sites. Using a cyclic sampling design (Burrows et al., 2002; Hudelson and Clayton, 2015; Orr et al., 2014), a 170 m×100 m (1.7 ha) plot was established at each site (Fig. 1) and a pattern of sampling was used to provide information about all lag distances (i.e., the range over which autocorrelation will be calculated). From the right upper corner to the left upper corner, the sampling intervals were $10,35,85$, and $100 \mathrm{~m}$, and from the top boundary of the field plot to the bottom boundary, the intervals were 10 , $35,85,95,120$, and $170 \mathrm{~m}$ (for a total of 36 measurement points). A cyclic design can increase the sampling efficiency by optimizing the placement of sampling points to provide the most information for geostatistical analysis with the lowest number of samples possible (Bogaert and Russo, 1999). This design maximizes efficiency by reducing over-sampling at small lag distances (Orr et al., 2014). Moreover, allowing for the possibility of important variability occurring and very fine spatial scales, a nested design was also employed within the overall cyclic sampling pattern. For this nest, a cycle of $0.5,2,4.5 \mathrm{~m}$ was applied in both cardinal directions (i.e., west to east and north to south $(\mathrm{n}=20)$. We assumed that our nested sampling locations provided a good representation of the micro-scale spatial variations within each of the field sites. There were also two additional sampling points that were strategically located in the plot to increase the sampling efficiency and capture the most information for geostatistical analysis. They were strategically located near other points in a way to increase pairs of lag classes between 20 to $25 \mathrm{~m}$. This yielded a total of 58 sampling points at each site for a total of 116 measured points in this study. A differential global positioning system device was used to locate the sampling points (latitude and 
longitude) with more than $20 \mathrm{~cm}$ accuracy. This sampling protocol enabled us to have lag distances between 0.5 and $197 \mathrm{~m}$ in the plot.

\section{Soil sample analysis}

One undisturbed soil sample was collected using stainless steel cylindrical cores with an inner diameter of $8 \mathrm{~cm}$ and a height of $5 \mathrm{~cm}\left(\sim 250 \mathrm{~cm}^{3}\right.$ volume $)$ in each sampling point to quantify water retention and hydraulic conductivity. With the 5-cm height sampling cylinders, we collected the soil samples at the depth increment of 5 to $10 \mathrm{~cm}$ as soil biochemical activities are representative and dominant within this soil layer; moreover, the shallow $0-5 \mathrm{~cm}$ soil surface was preclude as it can be impacted by crusting, excess dryness and other extreme effects. For chemical and microbial analyses, we used a push probe $(2 \mathrm{~cm}$ inner diameter) to collect and composite four soil-core samples ( $\sim 60 \mathrm{~cm}^{3}$ volume) at the same depth increments. The push probe was co-located within a $10 \mathrm{~cm}$ radius of the undisturbed soil-core sampling point. It is worth mentioning that the degree of spatial heterogeneity in soil properties is dependent on the support of the observations (i.e., the volume of soil material). In this study, we used composited samples (n: 4) for chemical and microbial analysis. These samples are known to be more heterogeneous by nature. Disturbed samples were put in Whirl-Pak ${ }^{\circledR}$ (Nasco, Fort Watkins, Wisconsin) sterile sampling bags and preserved and transported in an icebox to the laboratory. Samples for microbial characterization were kept frozen at $-86^{\circ} \mathrm{C}$ until they were freeze-dried in preparation for analysis.

Using the undisturbed cores, water retention was determined with the evaporation method (Schindler et al., 2010) using a HYPROP device (UMS GmbH, Munich, Germany). Matric potential was automatically recorded by two tensiometers at two depths within the saturated soil cores. The gravimetric water content of the samples was recorded twice daily for up to 14 days. Data points of the retention and unsaturated hydraulic conductivity curves were calculated with 
the HYPROP 2011 software (UMS GmbH, Munich, Germany) based on the mean tension potential of the two tensiometers and water contents as detailed in Kiani et al. (2017).

The soil water retention for moderate-to-dry moisture ranges was evaluated with a WP4-T potentiometer (Decagon Devices, Inc., Pullman WA, USA) based on the chilled-mirror dew-point technique (Schelle et al., 2013). Seven different amounts of water were added to $5 \mathrm{~g}$ dry weight of soil in plastic cups. The cups were closed tightly, and the samples were allowed to equilibrate for 24 hours. When the water potential of each sample was in equilibrium with the vapor pressure of the WP4-T measurement chamber, water tension was recorded. Sample weight was determined immediately after measurement and related to the oven-dry weight (at $105^{\circ} \mathrm{C}$ ) to obtain the corresponding water content. The constrained van Genuchten (1980) model was fitted to the results from the evaporation method (HYPROP) and WP4-T measurements. At the end of each measurement campaign, the soil samples were oven dried at $105^{\circ} \mathrm{C}$ for $24 \mathrm{~h}$ to derive bulk density and total porosity assuming a particle density of $2.65 \mathrm{~g} \mathrm{~cm}^{-3}$.

Macroporosity was computed from the soil water retention data by subtracting the saturated water content from the water content at field capacity ( $\mathrm{FC} ;-33 \mathrm{kPa}$ water potential), which corresponds to pore diameters larger than $9 \mu \mathrm{m}$. PAW capacity was also calculated as the differential volumetric water content between field capacity $(-33 \mathrm{kPa})$ and the permanent wilting point (PWP; -1500 kPa).

With the aim of extracting an integrated indicator of soil physical quality, the S-index was calculated as the magnitude of the slope of the soil water retention curve at the inflection point when the curve was expressed as gravimetric water content versus the natural logarithm of the pore water tension head (Dexter, 2004). 
After grinding a portion of the composited, disturbed samples, we determined the concentrations of SOC and STN with a dry combustion method using a Costech ECS 4010 Elemental Analyzer (Costech Analytical Technologies Inc., Valencia, CA, USA). The SOC density was calculated by multiplying the SOC concentration $\left(\mathrm{g} \mathrm{C} \mathrm{kg}^{-1}\right.$ soil $) \times$ bulk density $(\mathrm{g}$ $\left.\mathrm{cm}^{-3}\right) \times$ soil thickness $(\mathrm{cm}) \times 10$ (conversion factor). The soil $\mathrm{pH}$ was measured using a 1:2 soilto-water ratio (Mclean, 1982).

Using composited samples, we characterized soil microbial communities using phospholipid fatty acid (PLFA) analysis. Polar lipids were extracted from freeze-dried samples using a modified Bligh and Dyer protocol (Hannam et al., 2006). The standardized X: Y $\omega$ Z nomenclature for fatty acids was used to identify PLFAs, where $\mathrm{X}$ is the number of carbon atoms, $\mathrm{Y}$ is the number of double bonds, and $\mathrm{Z}$ is the position of the first double bond from the aliphatic end $(\omega)$ of the molecule (Quideau et al., 2016). Prefixes "i" and "a" indicate branching at the second and third carbon atom, respectively, from the $\omega$ end, and the suffix "c" corresponds to a c transfiguration. Adding them together, all of the PLFA biomarkers with 14 to 20 carbon atoms were considered to be representative of the total PLFA concentration of the microbial community in our soils. The total of the PLFAs was used as an index of microbial biomass carbon.

Candidate terrain covariates were derived from airborne LiDAR (Light Detection and Ranging) measurements with vertical accuracy of $30 \mathrm{~cm}$. Available LiDAR spatial resolution was $2 \mathrm{~m} \times 2 \mathrm{~m}$ with a horizontal accuracy of $50 \mathrm{~cm}$. The LiDAR method uses light in the form of a pulsed laser to measure variable distances to the Earth. A LiDAR measurement system basically consists of a laser, a scanner, and a specialized GPS receiver. Topographic LiDAR typically uses a near-infrared laser to map the land (Gatziolis and Andersen, 2008). The LiDAR-derived data in our study included terrain elevation, curvature, slope, aspect, hill shade, and DTW using ArcGIS 
10.3 (ArcGIS $\left.^{\odot}\right)$. DTW was obtained from the wet-areas delineation algorithms across the landscape, using the flow channels and shorelines (Murphy et al., 2011). The values of terrain covariates at each sampling point were obtained based on the nearest LiDAR data according to the point coordinate.

\section{Classical statistical analysis}

The datasets were analyzed to determine the following descriptive parameters: maximum, minimum, mean, median, and standard deviation (SD). Determining whether the means of soil properties differed significantly between the two land-use types, the Kruskal-Wallis test on ranks was used because the residuals did not follow normal distribution although they met the assumption of variance homogeneity. Spearman rank correlations were used to initially explore the existence and strength of relationships among soil properties and with terrain covariates.

The PLFAs with 14 to 20 carbons were used to analyze the microbial communities except for rare PLFAs which were found in merely one or two samples. Data groupings were tested for significant differences in the NMS analysis using a multi-response permutation procedure (MRPP). The MRPP test generates $\mathrm{P}, \mathrm{T}$, and A values indicating probability value, separation among groups, and within-group homogeneity compared to random expectation. The indicator species analyses were performed on the data groupings which were different in the MRPP test. This statistical method generates an indicator value based on the abundance and frequency of a particular PLFA in a given data grouping. A larger indicator value represents a stronger relationship between the PLFA and the given data grouping. The statistical significance of the indicator value was tested against a randomized Monte Carlo test. All analyses were conducted using PCORD software (version 5, MjM Software Design, Gleneden Beach, OR, USA). 


\section{Geostatistical analysis}

Geostatistics uses a semivariogram to quantify and model spatial autocorrelation and, subsequently, to provide parameters for optimal spatial interpolation, which is known as the kriging method (Webster and Oliver, 2007). Our measured data were used to calculate the experimental semivariogram, which was then fitted by authorized theoretical models, i.e. linear, gaussian, spherical, and exponential. Three major parameters could be derived from the fitted model, i.e. nugget $(\mathrm{C} 0)$, sill $(\mathrm{C}+\mathrm{C} 0)$, and autocorrelation range. All three can characterize the spatial structure of variables of interest at a given scale. The total variance ( sill, $\mathrm{C}+\mathrm{C} 0$ ) is expressed as the summary of the structural variance $(\mathrm{C}$, variance explained by spatial autocorrelation) and the nugget effect $(\mathrm{C} 0$, variance occurring at a smaller scale than the field sampling and from the experimental error) (Liu et al., 2013). The spatial autocorrelation range represents the maximum distance within which variables exhibit internal spatial dependence. To determine the magnitude of spatial dependence, the percentage of total variance (sill) explained by random variance $(\mathrm{C} 0)$ was calculated as a nugget ratio (Cambardella et al., 1994).

Considering the availability of ancillary information, the level of required expertise, and the constraints on the size of the data set, OK and coK methods were used for the spatial interpolation of the PAW, SOC concentration, and $\mathrm{MBC}$ in the 5-10 cm soil depth increment across our native grassland and cultivated land sites. The general equations of the OK (Eq. 1) and coK (Eq. 2, Fig. 4) methods are (Webster and Oliver, 2007):

$$
\begin{aligned}
& \hat{Z}\left(x_{0}\right)=\sum_{i=1}^{n} \lambda_{i} Z\left(x_{i}\right) \\
& \hat{Z}\left(x_{i 0}\right)=\sum_{i=1}^{N n} a_{i} Z\left(X x_{i}\right)+\sum_{i=n+1}^{n+N} b_{i} Y\left(x_{i}\right)
\end{aligned}
$$


where $\hat{Z}\left(x_{i 0}\right), Z\left(x_{i}\right), Y\left(x_{i}\right)$, and $\mathrm{n}$ are the predicted value, primary variable, secondary variable, and the number of samples, respectively. The $\lambda_{i}, a_{i}$, and $b_{i}$, are kriging weights.

The leave-one-out cross-validation analysis was used to evaluate how effective the fitted variograms were (Fig. 3). In cross-validation analysis, each measured point in the spatial domain is individually removed from the domain one at a time, and its value estimated as though it were never there. Subsequently, the original data point is placed back in the dataset, and the next point is removed and estimated, and so forth (Robertson, 2008). This recurrent, systematic approach generates an array of actual versus estimated data values which can be compared against the 1:1 agreement line by means of a least square linear regression. The criteria used for contrasting the performance of the evaluated geostatistical methods were Nash-Sutcliffe efficiency (NSE ), mean prediction error (MPE), standard error of prediction (SE predict), and root mean square prediction error (RMSPE) calculated as follows:

$$
\begin{aligned}
& N S E=1-\frac{\sum_{i=1}^{n}\left[\hat{Z}\left(x_{i}\right)-Z\left(x_{i}\right)\right]^{2}}{\sum_{i=1}^{n}\left[Z\left(x_{i}\right)-\bar{x}\right]^{2}} \\
& M P E=\frac{1}{N} \times \sum_{i=1}^{N}\left[\hat{Z}\left(X_{i}\right)-Z\left(X_{i}\right)\right] \\
& S E \text { predict }=S D \sqrt{1-r^{2}} \\
& R M S P E=\sqrt{\frac{1}{N} \times \sum_{i=1}^{N}\left[\hat{Z}\left(X_{i}\right)-Z\left(X_{i}\right)\right]^{2}}
\end{aligned}
$$

where $\bar{x}$ is the mean of the primary variable, SD is the standard deviation of the measured data, and $\mathrm{r}^{2}$ is the proportion of variation explained by the best-fitted line. The geostatistical analysis was performed with the GS+ software (version 10.0) and the distribution contour plots were produced with SigmaPlot software (version 11.0) without using any data-smoothing function. 


\section{Results}

\section{Classical statistical analyses of soil properties}

The overall means of Van Genuchten (VG) parameters for our soil-moisture retention curves consistently differed between native grassland and irrigated cultivated land (Table 1). The saturated water content was $11 \%$ higher in NG $(P<0.05)$, while PAW was found to be three times greater in the cultivated land; this outcome was driven by a 1.3-times significantly higher water content at field capacity (FC) for IC than that found in the NG samples (Table 1). Additionally, a reciprocal 1.3-times greater presence of draining pores (macropores; $>9 \mu \mathrm{m}$ diameter) in these sandy soils under perennial native grasses ( $\mathrm{NG}>\mathrm{IC})$ implies faster water infiltration, conductivity, redistribution, and percolation across the NG soil profiles. A clear significant difference was also found in the S-index data (i.e., the slope of moisture curves at their inflection point) between NG and IC lands, with magnitudes of 0.11 for NG vs. 0.06 for IC $(P<0.05$; Table 1$)$. Regarding the fitting performance of the VG models, root mean square errors for the moisture curve of each landuse system ranged from 0.003 to $0.020 \mathrm{~cm}^{3} \mathrm{~cm}^{-3}$ indicating an effective fitting of the VG models to the measured data.

The NG soil exhibited a two-fold faster hydraulic conductivity under unsaturated conditions (unsat. $\mathrm{K}$ at $-10 \mathrm{kPa}$ water tension) than the IC soil $(P<0.05$; Table 1$)$. Conversely, this clear effect of land use on water movement capacity did not translate into differences in hydraulic conductivity at saturation. Root mean square error values of modelled hydraulic conductivity $(\mathrm{K})$ were high across all data sets $\left(0.21 \mathrm{~cm} \mathrm{day}^{-1}\right.$; data not shown $)$, indicating modest fitting, which is probably in part a result of extrapolation into the saturated zone of the water retention curve. Although both SOC concentration and SOC density showed no statistical differences linked to land use, STN concentrations were significantly higher in the cultivated land 
(Table 1). The soil $\mathrm{C} / \mathrm{N}$ ratio mirrored this difference; it was $12 \%$ narrower in $\mathrm{IC}$ than in $\mathrm{NG}(P<$ 0.05; Table 1).

Soil microbial biomass was significantly greater in the cultivated land with a concentration

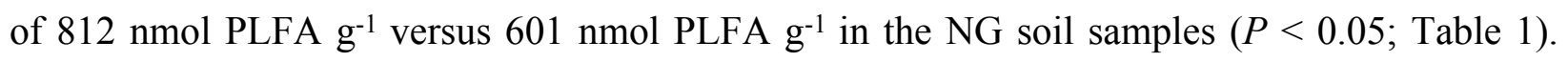
Separation in the composition of the microbial communities between the NG and the IC lands was statistically significant as evidenced by the MRPP analysis of the PLFA data $(P<0.001$; data not shown). Similarly, the A value, which indicates within-group homogeneity, was 0.04 for the microbial communities between the two sampling sites. Although the A value shows that withingroup variability is considerable, the large $T$ value (15.6) indicates distinctive separation between two groups. The indicator species analysis detected six significant PLFAs preferentially present in the NG soils, but no specific biomarker was detected for the IC (Table 2). More specifically, the 15:1i, 17:1a, and 17:168c PLFAs indicative of Gram-negative bacteria, and also a unique actinobacterial biomarker (17:0 10 methyl), were associated with the NG.

Significant negative correlations were found between the DTW and the following biophysical soil properties (Fig. 2) in NG: SOC, STN, and MBC. Also, DTW was positively correlated with bulk density $(\mathrm{r}<0.3 ; P<0.05)$. Similar to the NG, the DTW had negative correlations with $\mathrm{MBC}(P<0.05)$ in IC. It was also positively correlated with the $\mathrm{C} / \mathrm{N}$ ratio $(\mathrm{r}=0$. 505; $P<0.01)$. Among all topography variables, the elevation was significantly correlated with the majority of biophysical soil properties in cultivated land with negative correlations with FC water content, $\mathrm{PAW}$, hydraulic conductivity, $\mathrm{SOC}, \mathrm{C} / \mathrm{N}$ ratio, fungal-to-bacteria ratio, and $\mathrm{pH}$.

\section{Geostatistical modeling}

The mean and median were used as central tendency estimates, while the minimum, maximum, skewness, kurtosis, and standard deviation (SD) values were used as descriptors of 
variability from each separate site. We observed that water content at FC, PAW, sat. K, SOC, and STN were highly positively skewed (Table 1), as shown by the distinctive asymmetry in their distributions. In addition, the distribution of water content at FC, PAW, sat. K, SOC, and STN peaked more than a Gaussian distribution according to the Kurtosis values. The highly skewed distributions of PAW and SOC, particularly in our native grassland may, in part, be considered evidence of spatial heterogeneity with extreme values characteristic of landscapes where agricultural management (e.g., tillage, irrigation) have not fully smoothed underlying natural variation features. The relatively high variability of curvature (at $2 \mathrm{~m}-\mathrm{by}-2 \mathrm{~m}$ resolution and using eight surrounding neighbors) and elevation in the NG site can support this notion (Table 1). The addition of cattle manure during field grazing events in NG may also have led to accumulation patches of enriched SOC.

With the aim of selecting suitable terrain covariates, we assessed the three soil properties of interest (i.e., SQ indicators: SOC concentration, PAW, and MBC) alongside highly correlated terrain variables (Fig. 2) to examine which candidate covariate(s) led to the lowest residual sums of squares (RSS) and highest $\mathrm{R}^{2}$ as derived through fitted cross-variograms. Using covariates consistently resulted in a substantial reduction in the RSS of the variographies for all assessed soil properties. Of the assessed terrain attributes, the best covariate for PAW was terrain slope in NG and elevation in IC (Table 3; Fig. 2 and Supplementary Fig. S1). Interestingly, DTW was the optimal covariate for both the SOC concentration and $\mathrm{MBC}$ in both land-use systems (Table 3; Fig. 2, 4, and Supplementary Fig. S2), implying an overarching influence of terrain wetness on these two key soil biological responses irrespective of the land management scenarios.

The autocorrelation range was typically 40 to $126 \mathrm{~m}$ (Table 3 ), and the longest autocorrelation ranges were observed with the coK method where terrain covariates contributed to 
these longer range spatial predictions. Congruently, the nugget ratio exhibited prominent reductions when applying the terrain covariates (Table 3), likely indicating tighter spatial structure and increased predictability. The standard error of the predictions had the lowest value in coK for all soil variables (Table 3). Furthermore, the coK method had low RMSPE (Table 3), which suggests that this approach is good interpolator. The goodness of fit ( $\mathrm{R}^{2}$ values) between the measured and predicted data also indicated that coK performed best across all variables at both land uses.

The mapped means of SOC concentration, PAW, and MBC amply changed within the different distance ranges over NG and IC fields (Fig. 4, Supplementary Figs. S1 and S2), which indicates that the correlations of the covariates with the primary variate vary with spatial locations in this relatively heterogeneous prairie site. We also found that the $\mathrm{OK}$ and coK approaches differed with respect to their spatial patterns of prediction errors. The estimated uncertainty of soil SOC concentration, PAW, and MBC was very high with the OK method, but clearly reduced with the coK (Fig. 5, Supplementary Figs. S3 and S4). As indicated above, the selected SQ indicators exhibit high spatial variability by nature and, hence, approaches that demonstrate systematic reductions in their uncertainty are avidly sought after for improving predictive mapping. 


\section{Discussion}

\section{Soil quality as a response to contrasting land use systems.}

Compared to the cultivated land, the native grassland had greater saturated water content and doubled the hydraulic conductivity (at $-10 \mathrm{kPa}$ water potential). This outcome directly reflects the higher abundance of macropores in NG soils (Table 1), which can readily intake, store, and transport ample amounts of water at low tensions. However, in an apparent incongruency, PAW was almost triple in the IC land (0.069 vs. $\left.0.024 \mathrm{~m}^{3} \mathrm{~m}^{-3}\right)$, which can be largely attributed to a greater volume of smaller-size pores in these IC soils. For more than two decades this cultivated land was continuously used as cropland, and it had recently (in the summer prior to our field sampling) been converted to pasture. Our results imply that previous annual cropping activities, including tillage and recurrent equipment traffic, led to soil compaction, which is known to alter soil pore distribution by reducing macroporosity (Pagliai et al., 2004). Moreover, animal treading may further compress large pores into relatively smaller pores near the ground surface (Drewry et al., 2008). Hence, we postulate that the creation of smaller and more frequent size pores as a longterm response to management change could have increased PAW in the cultivated land.

A greater MBC in the cultivated land could further support our hypothetical explanation for a higher volume of smaller pores in IC (Table 1). Even in coarse-textured soils, microorganisms can influence the formation of aggregates and stabilization of structure (Six et al., 2004), provided that microbes inhabit the pore space between microaggregates (20-250 $\mu \mathrm{m}$ size; Chenu, 1989). It seems plausible that a facilitation of increased microaggregation mediated by microbial activity in combination with small pores derived from soil compaction resulted in higher PAW and higher water content at field capacity in our cultivated land. Daynes et al. (2013) also showed that PAW increased in the presence of living plant roots and soil microbes because of maximization in the 
distribution of relatively finer pores that are capable of holding water available for vegetation. Our study extends the existing literature by documenting clear differences in soil pore water interactions and microbial functions across competing land-use types.

Differences in microbial community structure between grassland and cultivated land are most likely related to variations in the quantity and quality of nutrients being supplied to the soil (Juma, 1994; Grayston et al., 2004; Khalili et al., 2016). Although the SOC concentration did not differ between the two land-use sites, the irrigated cultivated land had significantly higher nitrogen content leading to a lower $\mathrm{C} / \mathrm{N}$ ratio $(P<0.05)$. The narrower $\mathrm{C} / \mathrm{N}$ ratio in our cultivated soils may have revealed less limiting nitrogen status (Quideau et al., 2013) in the IC soil after decades of intense cropping history, including $\mathrm{N}$ fertilization and the introduction of legumes, which caused the greater MBC in the IC land (Li et al., 2018). Moreover, the NG soil was characterized by a higher abundance of Gram-negative bacteria, actinobacteria, and anaerobic bacteria as main microbial biomarkers (Table 2). Previous studies also indicated Gram-negative bacteria as unique biomarkers of grazed perennial grassland (Steenwerth et al., 2002; Geisseler et al., 2016) and a greater abundance of Gram-positive bacteria in cultivated sites. It seems that converting the native grassland to cultivated land decreased the relative abundance of Gram-negative bacteria while increasing the proportion of Gram-positive bacteria. Gram-positive bacteria can mineralize recalcitrant organic compounds when requiring available inorganic $\mathrm{N}$ to invest in synthetizing extracellular enzymes, while Gram-negative bacteria target labile $\mathrm{C}$ compounds requiring fewer extracellular enzymes and can therefore invest in transport proteins that target organic $\mathrm{N}$ (Treseder et al., 2011). Shifting from Gram-negative bacteria to Gram-positive bacteria corresponded with increasing litter quality and $\mathrm{N}$ availability in irrigated cultivated land with possible greater contents of stable soil C. These results further support the interaction between microbial functions and 
higher volume of smaller pores in the cultivated land. Recurrent tillage cultivation breaks up soil aggregates which would expose labile organic $\mathrm{C}$ (protected inside of soil aggregates) to microbial decomposition reducing the labile $\mathrm{C}$ concentration, and any remaining $\mathrm{C}$ from these processes can be transformed into more stable C (Figueiredo et al., 2010; Li et al., 2018).

When the S-index value as an indicator of soil physical quality is greater than 0.05 , indicates a "very good" physical or structural quality, and $0.035 \leq \mathrm{S}$-index $<0.050$ indicates "good physical quality" (Dexter, 2004). Although our S-index results showed good to very good structural quality $(0.031 \leq \mathrm{S}$-index $\leq 0.197$; Table 1$)$ in the $\mathrm{NG}$, this might mainly reflect soil matrix attributes rather than structural characteristics for soils with a narrow pore-size distribution (Dexter et al., 2008) as found in our field sites. Consequently, it appears that the S-index should be interpreted cautiously, and needs to be assessed along other SQ indicators when attempting to quantify the physical quality of rigid to moderately expansive soils (Reynolds et al., 2009).

\section{Topography variables in relation to soil quality indicators in different land-uses}

Among the six topography variables, DTW and elevation had both the greatest association with the assessed soil quality indicators (Fig. 2). The mean DTW in native grassland was $1.03 \mathrm{~m}$ depth while in irrigated pasture it was only $0.36 \mathrm{~m}$, which could be another reason that conditions were more favorable for microbes and greater MBC in the cultivated land. Both $\mathrm{MBC}$ and SOC concentration were significantly related to DTW in both land use systems $(P<0.01)$, perhaps indicating the sensitivity of the formation of soil organic matter and microbial activity to the capacity of the soil to hold available water. Soil moisture availability directly impacts the activity of microorganisms in a way that their activity decreases as the soil becomes dry (Curtin et al., 2012). With regards to SOC, previous studies also showed a significant positive relationship between water availability and SOC (Kiani et al., 2017). Water availability could increase the 
production of plant biomass, root exudation, and residues that can be incorporated into the soil. It could, over the long term, also feedback into additional organic carbon accrual (Dinwoodie and Juma, 1988). The highest SOC concentration ( $>25 \%)$ was observed at a low estimated water table depth $(<0.2 \mathrm{~m})$ and elevation, where the mass of the fungi community was in a higher range ( $>$ $110 \mathrm{nmol} \mathrm{g}^{-1}$ soil) in both lands. In grassland, the lower capacity of water availability for plants was significantly related to the deeper water table while a similar relationship was not observed in the irrigated pasture. The correlation implies that in the native grassland, which does not receive regular irrigation, DTW is a key geomorphology controller of soil quality. Model developers of soil quality in grasslands should take this into account.

Overall, a relationship $(\mathrm{r}>-0.36 ; P<0.01)$ between SOC and terrain elevation was observed for both land-uses with a decrease in SOC when elevation increased (Fig. 2). A similar relationship was observed between $\mathrm{STN}$ and elevation in native grassland $(\mathrm{r}=-0.39 ; P<0.01)$. Our results are in agreement with earlier studies which reported relatively low values of SOC and STN at higher terrain elevations (Zhao et al., 2015). It is plausible that as terrain elevation decreases, soil moisture content and availability tend to increase (Hook and Burke, 2000), and consequently, increasing plant productions which in turn increases SOC input and accumulation (Pei et al., 2010; Li and McCarty, 2019). It is also possible that the accumulation of SOC at the lower position could be caused by soil erosion which leads to residue deposition and redistribution of labile organic carbon in the surface soil (Lal, 2003; Li et al., 2017).

\section{Improving mapping of soil quality indicators using the topography variables}

The PAW, SOC concentration, and MBC were strongly spatially dependent in cultivated land (nugget ratio $<18 \%$; Table 3) compared to the native grassland. Glendell et al. (2014) also found a stronger degree of spatial dependence of total carbon and the $\mathrm{C} / \mathrm{N}$ ratio in agricultural land 
$(<24 \%)$ than in grasslands (37 to $71 \%$ ). The stronger degree of spatial dependence and longer autocorrelation range in cultivated lands indicates a homogenization of the spatial variability of soil properties (Glendell et al., 2014; Qiu et al., 2016). This effect could be a result of intensive, long-term agricultural activities such as tillage, irrigation, fertilization, and harvest, which have been applied uniformly across this field.

In our study, we systematically explored two geostatistical methods to provide a detailed spatial-resolution prediction and visualization of PAW, SOC concentration, and MBC in soils of native grasslands and cultivated lands. A direct way to check the interpolation performance is by plotting the predicted values against the observed values. A comparison of the cross validation of the OK and coK approaches indicated that the coK method had the best performance (Table 3; Fig. 3). In line with this finding, Chen et al. (2009) reported that compared to ordinary kriging, the coK method was useful for reducing requirements of sampling quantities and intensity. It also made it possible to save sample collection time under the premise of maintaining interpolation accuracy. The coK method demonstrated a clear improvement in the accuracy of spatial estimations of the SOC concentration and MBC when DTW was incorporated as a covariate (Table 3). Furthermore, when focusing on PAW, the coK method also had the best performance when terrain slope and elevation were the selected covariates for the NG and IC fields, respectively. The MPE also showed that bias estimation was considerably reduced when the coK was applied for spatial prediction (Table 3). Our results are consistent with earlier reports showing a clear advantage of coK over OK for predicting the spatial variation of SOC stock (Ceddia et al., 2015; Guenette and Hernandez-Ramirez, 2018), saturated hydraulic conductivity (Motaghian and Mohammadi, 2011), heavy metals (Chen et al., 2009) and topsoil gravel and subsoil clay (Odeh et al., 1995). 
Graphic visualization of the mean and uncertainty for predicted values across our field sites provides opportunities to identify spatial patterns and to conduct comparisons amongst geostatistical approaches (Hengl et al., 2004). Overall, our mean maps for selected soil properties (PAW, SOC concentration, and MBC) showed similarities in estimated values when comparing OK with the coK method; however, a major difference became evident when contrasting standard deviation maps derived from OK versus those from coK (Fig. 5, Supplementary Figs. S3 and S4). It is noticeable that the incorporation of topographic variables as covariates substantially reduces the estimated uncertainty of the predictions by about half. Furthermore, the OK uncertainty maps showed abrupt textural changes with sharp increases in predicted standard deviation, particularly in field areas that were distant from our measured points. Conversely, the coK maps exhibited much lower, coherent uncertainty patterns across the space, and even in areas away from our measured sampling points. Our strategy of soil samples collection (nested cyclic sampling design) could increase the sampling efficiency by reducing over-sampling at small lag distances. However, in our case, due to the large unsampled area in some field areas, the kriging variance for these spatial estimations particularly MBC in the IC field had high uncertainty which could be improved by strategically implementing sampling at targeted field locations.

Our geostatistical analyses suggest that the combination of specific topographic covariates in coK techniques provided an enhanced ability to incorporate ancillary information into predictive soil mapping of SQ indicators. We suggest undertaking additional validation of our findings in new, independent field sites; such efforts will evaluate the robustness and usefulness of our derived spatial models over comparable landscapes and lead to the optimization of these predictive mapping tools. 


\section{Conclusion}

This study examined the spatial variation of sensitive SQ indicators in two contrasting landuse systems along with their relationships with several topography variables. Overall, converting native grassland to cultivated lands detrimentally altered the soil structural characteristics. However, a number of factors contributed to better conditions for microbial growth in cultivated land including more availability of water and nutrients. This interaction emphasizes the interest of assessing several SQ indicators simultaneously to infer multiple soil functions and the status of ecosystem services in land-use systems. In addition, we observed different relationships between SQ indicators and topographic variables in our study. In general, DTW ( $\sim$ water table depth) and terrain elevation variables were key geomorphology controllers of SOC and MBC in both lands suggesting that SQ model developers can take these relationships into account.

Also, we examined two common geostatistical methods for capturing and predicting field spatial variability of PAW, SOC concentration, and MBC. Our results showed that integrating high spatial-resolution topographic information (e.g., DTW, elevation, or slope) derived from remote sensing into the geostatistical coK method improved the prediction ability substantially compared to the OK method. Such improved mapping applications would benefit studies in areas with limited data access or where there is need to extrapolate findings from representative sites to larger regions.

Overall, the identification of spatial patterns of soil properties in agricultural lands provides holistic visualization tools to landowners for implementing and improving management practices that will eventually lead to more sustainable production. There is a need to continue developing explicit spatial upscaling information about specific soil properties that are linked to key ecosystem functions under a broader variety of land-use systems at other soil depths than in our study and in finer-textured soils. 


\section{Acknowledgement}

The authors wish to thank Lewis Fausak, Karin Lindquist, and Kris Guenette for their assistance during field sampling at the Mattheis sites and laboratory analyses. The authors acknowledge Germar Lohstraeter (Alberta Agriculture \& Forestry), Don Armitage (Mattheis Research Ranch), and Jela Burkus for the technical support to perform this study. We thank the associate editor and anonymous reviewer for their insightful comments. The research project was jointly supported by our funding partners, Alberta Livestock and Meat Agency (ALMA) Sustainability, and the Rangeland Research Institute (RRI) at the University of Alberta. This manuscript is derived from the M.Sc. thesis by Ms. M. Kiani, University of Alberta, Canada (Kiani, 2016). 


\section{References}

AGRASID. Agricultural Region of Alberta Soil Inventory Database. 2015. URL:http://www1.agric.gov.ab.ca/\$department/deptdocs.nsf/all/sag3249.

Bogaert, P., Russo, D., 1999. Optimal spatial sampling design for the estimation of the variogram based on a least squares approach. Water Resour Res. 4, 1275-1289.

Burrows, S.N., Gower, S.T., Clayton, M.K., Mackay, D.S., Ahl, D.E., Norman, J.M., Diak, G., 2002. Application of geostatistics to characterize leaf area index (LAI) from flux tower to landscape scales using a cyclic sampling design. Ecosystems, 5, 667-679.

Burst, M., Chauchard, S., Dambrine, E., Dupouey, J.L. and Amiaud, B., 2020. Distribution of soil properties along forestgrassland interfaces: Influence of permanent environmental factors or land-use after-effects?. Agriculture, Ecosystems \& Environment, 289, p.106739.

Cambardella, C. a., Moorman, T.B., Parkin, T.B., Karlen, D.L., Novak, J.M., Turco, R.F., Konopka, a. E., 1994. Field-Scale Variability of Soil Properties in Central Iowa Soils. Soil Sci. Soc. Am. J. 58, 1501. doi:10.2136/sssaj1994.03615995005800050033x

Ceddia, M.B., Villela, A.L.O., Pinheiro, T.F.M., Wendroth, O., 2015. Spatial variability of soil carbon stock in the Urucu river basin, Central Amazon-Brazil. Sci. Total Environ. 526, 58-69. doi:10.1016/j.scitotenv.2015.03.121

Chantigny, M.H., 2003. Dissolved and water-extractable organic matter in soils: a review on the influence of land use and management practices. Geoderma, 113(3-4), pp.357-380.

Chen, T., Liu, X., Li, X., Zhao, K., Zhang, J., Xu, J., Shi, J., Dahlgren, R.A., 2009. Heavy metal sources identification and sampling uncertainty analysis in a field-scale vegetable soil of Hangzhou, China. Environmental Pollution, 157, pp.1003-1010.

Chen, T., Chang, Q., Liu, J., Clevers, J.G.P.W. and Kooistra, L., 2016. Identification of soil heavy metal sources and improvement in spatial mapping based on soil spectral information: A case study in northwest China. Science of the total environment, 565, pp.155-164.

Chenu, C., 1989. Influence of a fungal polysaccharide, scleroglucan, on clay microstructures. Soil Biol. Biochem. 21, 299- 
305. doi:10.1016/0038-0717(89)90108-9

Curtin, D., Beare, M.H., Hernandez-Ramirez, G., 2012. Temperature and Moisture Effects on Microbial Biomass and Soil Organic Matter Mineralization. Soil Sci. Soc. Am. J. 0, 0. doi:10.2136/sssaj2012.0011

Davis, J.C. and Sampson, R.J., 1986. Statistics and data analysis in geology (Vol. 646). New York et al.: Wiley.

Daynes, C.N., Field, D.J., Saleeba, J.A., Cole, M.A., McGee, P.A., 2013. Development and stabilisation of soil structure via interactions between organic matter, arbuscular mycorrhizal fungi and plant roots. Soil Biol. Biochem. 57, $683-694$. doi:10.1016/j.soilbio.2012.09.020

Dexter, a R., 2004. Soil physical quality Part I. Theory, effects of soil texture, density, and organic mailer, and effects on root growth. Geoderma 120, 201-214. doi:10.1016/j.geodermaa.2003.09.005

Dexter, A.R., Czyz, E.A., Richard, G., Reszkowska, A., 2008. A user-friendly water retention function that takes account of the textural and structural pore spaces in soil. Geoderma 143, 243-253. doi:10.1016/j.geoderma.2007.11.010

Dinwoodie, G.D. and Juma, N.G., 1988. Factors affecting the distribution and dynamics of 14 C in two soils cropped to barley. Plant and soil, 110(1), pp.111-121.

Drewry, J.J., Cameron, K.C., Buchan, G.D., 2008. Pasture yield and soil physical property responses to soil compaction from treading and grazing - A review. Aust. J. Soil Res. 46, 237-256. doi:10.1071/SR07125

Elliott, E.T., 1986. Aggregate structure and carbon, nitrogen, and phosphorus in native and cultivated soils 1 . Soil science society of America journal, 50(3), pp.627-633.

Figueiredo, C.C.D., Resck, D.V.S. and Carneiro, M.A.C., 2010. Labile and stable fractions of soil organic matter under management systems and native cerrado. Revista Brasileira de Ciência do Solo, 34(3), pp.907-916.

Gatziolis, D., Andersen, H.E., 2008. A Guide to LIDAR Data Acquisition and Processing for the Forests of the Pacific Northwest. Gen. Tech. Rep. PNW-GTR-768 1-40. doi:Gen. Tech. Rep. PNW-GTR-768

Geisseler, D., Lazicki, P.A., Scow, K.M., 2016. Mineral nitrogen input decreases microbial biomass in soils under grasslands but not annual crops. Appl. Soil Ecol. 106, 1-10. doi:10.1016/j.apsoil.2016.04.015

Glendell, M., Granger, S.J., Bol, R., Brazier, R.E., 2014. Quantifying the spatial variability of soil physical and chemical 
properties in relation to mitigation of diffuse water pollution. Geoderma 214-215, 25-41. doi:10.1016/j.geoderma.2013.10.008

Grayston, S.J., Campbell, C.D., Bardgett, R.D., Mawdsley, J.L., Clegg, C.D., Ritz, K., Griffiths, B.S., Rodwell, J.S., Edwards, S.J., Davies, W.J. and Elston, D.J., 2004. Assessing shifts in microbial community structure across a range of grasslands of differing management intensity using CLPP, PLFA and community DNA techniques. Applied Soil Ecology, 25, 63-84.

Guenette, K.G., Hernandez-Ramirez, G., 2018. Tracking the influence of controlled traffic regimes on field scale soil variability and geospatial modeling techniques. Geoderma, 328, 66-78.

Hannam, K. D., Quideau, S. A., Kishchuk, B. E., 2006. Forest floor microbial communities in relation to stand composition and timber harvesting in northern Alberta. Soil Biology and Biochemistry, 38, 2565- 2575.

Hebb, Christina, Donald, Schoderbek, Guillermo, Hernandez-Ramirez, Daniel, Hewins, Cameron, N. Carlyle, Edward, Bork, 2017. Soil physical quality varies among contrasting land uses in Northern Prairie regions. Agric. Ecosyst. Environ. 240, 14-23.

Hengl, T., Heuvelink, G.B.M., Stein, A., 2004. A generic framework for spatial prediction of soil variables based on regression-kriging. Geoderma 120, 75-93. doi:10.1016/j.geoderma.2003.08.018

Hewins, D.B., Broadbent, T., Carlyle, C.N., Bork, E.W., 2016. Extracellular enzyme activity response to defoliation and water addition in two ecosites of the mixed grass prairie. Agric. Ecosyst. Environ. 230, 79-86. doi:10.1016/j.agee.2016.05.033

Hook, P.B. and Burke, I.C., 2000. Biogeochemistry in a shortgrass landscape: control by topography, soil texture, and microclimate. Ecology, 81(10), pp.2686-2703.

Hudelson, B.D., Clayton, M.K., 2015. Confidence Intervals for Autocorrelations Based on Cyclic Samples 90, 753-757.

Jenny, H., 1941. Factors of soil formation. McGraw-Hill, New York. Factors of soil formation. McGraw-Hill, New York.

Juma, N.G., 1994. A conceptual framework to link carbon and nitrogen cycling to soil structure formation. Agriculture, ecosystems \& environment, 51(1-2), pp.257-267.

Khalili, B., Ogunseitan, O.A., Goulden, M.L., Allison, S.D., 2016. Interactive effects of precipitation manipulation and 
nitrogen addition on soil properties in California grassland and shrubland. Appl. Soil Ecol. 107, $144-153$. doi:10.1016/j.apsoil.2016.05.018

Kiani, M. 2016. Soil Quality Dynamics and Spatial Heterogeneity in Grasslands and Cropping Systems in Western Canada. (M.Sc. thesis, University of Alberta) https://doi.org/10.7939/R3251FX8X

Kiani, M., Hernandez-Ramirez, G., Quideau, S., Smith, E., Janzen, H., Larney, F.J., Puurveen, D., 2017. Quantifying sensitive soil quality indicators across contrasting long-term land management systems: Crop rotations and nutrient regimes. Agriculture, Ecosystems \& Environment, 248,123-135.

Knotters, M., Brus, D.J., Voshaar, J.H.O., 1995. a Comparison of Kriging, Co-Kriging and Kriging Combined With Regression for Spatial Interpolation of Horizon Depth With Censored Observations. Geoderma 67, $227-246$. doi:10.1016/0016-7061(95)00011-c

Li, Z., Liu, C., Dong, Y., Chang, X., Nie, X., Liu, L., Xiao, H., Lu, Y. and Zeng, G., 2017. Response of soil organic carbon and nitrogen stocks to soil erosion and land use types in the Loess hilly-gully region of China. Soil and Tillage Research, 166, pp.1-9.

Li, J., Ramirez, G.H., Kiani, M., Quideau, S., Smith, E., Janzen, H., Larney, F. and Puurveen, D., 2018. Soil organic matter dynamics in long-term temperate agroecosystems: rotation and nutrient addition effects. Canadian Journal of Soil Science, 98(2), pp.232-245.

Li, X. and McCarty, G.W., 2019. Application of Topographic Analyses for Mapping Spatial Patterns of Soil Properties. In Geospatial Analyses of Earth Observation (EO) data. IntechOpen.

Liu, Z.-P., Shao, M.-A., Wang, Y.-Q., 2013. Spatial patterns of soil total nitrogen and soil total phosphorus across the entire Loess Plateau region of China. Geoderma 197-198, 67-78. doi:10.1016/j.geoderma.2012.12.011

Mclean, E.O., 1982. Soil pH and lime requirement. Methods Soil Anal. 9, 595-624. doi:10.2134/agronmonogr9.2.2ed.c12

Mirzaee, S., Ghorbani-Dashtaki, S., Mohammadi, J., Asadi, H., Asadzadeh, F., 2016. Spatial variability of soil organic matter using remote sensing data. Catena 145, 118-127. doi:10.1016/j.catena.2016.05.023

Mollard, F.P.O., Naeth, M.A., Cohen-Fernandez, A., 2014. Impacts of mulch on prairie seedling establishment: Facilitative to inhibitory effects. Ecol. Eng. 64, 377-384. doi:10.1016/j.ecoleng.2014.01.012 
Murphy, P.N., Ogilvie, J., Meng, F.R., White, B., Bhatti, J.S. and Arp, P.A., 2011. Modelling and mapping topographic variations in forest soils at high resolution: A case study. Ecological Modelling 22214),2314-2332.

Motaghian, H.R., Mohammadi, J., 2011. Spatial estimation of saturated hydraulic conductivity from terrain attributes using regression, kriging, and artificial neural networks. Pedosphere 21, 170-177. doi:10.1016/S1002-0160(11)60115-X

Nyamadzawo, G., Shukla, M.K. and Lal, R., 2008. Spatial variability of total soil carbon and nitrogen stocks for some reclaimed minesoils of Southeastern Ohio. Land Degradation \& Development, 19(3), pp.275-288.

Odeh, I.O.A., McBratney, A.B., Chittleborough, D.J., 1995. Further results on prediction of soil properties from terrain attributes: heterotopic cokriging and regression-kriging. Geoderma 67, 215-226. doi:10.1016/0016-7061(95)00007B

Oltean, G.S., Comeau, P.G. and White, B., 2016. Linking the depth-to-water topographic index to soil moisture on boreal forest sites in Alberta. Forest Science, 62(2), pp.154-165.

Orr, C.H., Predick, K.I., Stanley, E.H., Rogers, K.L., 2014. Spatial autocorrelation of denitrification in a restored and a natural floodplain. Wetlands 34, 89-100. doi:10.1007/s13157-013-0488-8

Pagliai, M., Vignozzi, N., Pellegrini, S., 2004. Soil structure and the effect of management practices. Soil Tillage Res. 79, 131-143. doi:10.1016/j.still.2004.07.002

Pei, T., Qin, C.Z., Zhu, A.X., Yang, L., Luo, M., Li, B. and Zhou, C., 2010. Mapping soil organic matter using the topographic wetness index: A comparative study based on different flow-direction algorithms and kriging methods. Ecological Indicators, 10(3), pp.610-619.

Qiu, W., Curtin, D., Johnstone, P., Beare, M. and Hernandez-Ramirez, G., 2016. Small-scale spatial variability of plant nutrients and soil organic matter: An arable cropping case study. Communications in soil science and plant analysis, 47(19), pp.2189-2199.

Quideau, S.A., McIntosh, A.C., Norris, C.E., Lloret, E., Swallow, M.J. Hannam, K., 2016. Extraction and analysis of microbial phospholipid fatty acids in soils. JoVE (Journal of Visualized Experiments), (114), pp.e54360-e54360.

Reynolds, W.D., Drury, C.F., Tan, C.S., Fox, C.A., Yang, X.M., 2009. Use of indicators and pore volume-function characteristics to quantify soil physical quality. Geoderma 152, 252-263. doi:10.1016/j.geoderma.2009.06.009 
Robertson, G.P., Crum, J.R., Ellis, B.G., 1993. The spatial variability of soil resources following long-term disturbance. Oecologia 96, 451-456. doi:10.1007/BF00320501

Robertson, G.P., 2008. GS+: Geostatistics for the environmental sciences. Gamma Design Software, Plainwell, Michigan USA, p. 165 .

Schelle, H., Heise, L., Jänicke, K., Durner, W., 2013. Water retention characteristics of soils over the whole moisture range: A comparison of laboratory methods. Eur. J. Soil Sci. 64, 814-821. doi:10.1111/ejss.12108

Schindler, U., Durner, W., von Unold, G., Muller, L., 2010. Evaporation Method for Measuring Unsaturated Hydraulic Properties of Soils: Extending the Measurement Range. Soil Sci Soc Am J 74, 1071-1083. doi:10.2136/sssaj2008.0358

Six, J., Bossuyt, H., Degryze, S., Denef, K., 2004. A history of research on the link between (micro)aggregates, soil biota, and soil organic matter dynamics. Soil Tillage Res. 79, 7-31. doi:10.1016/j.still.2004.03.008

Speight, J.G., 1980. The role of topography in controlling throughflow generation: a discussion. Earth Surface Processes, 5(2), pp.187-191.

Steenwerth, K.L., Jackson, L.E., Calderón, F.J., Stromberg, M.R., Scow, K.M., Caldero, F.J., 2002. Soil microbial community composition and land use history in cultivated and grassland ecosystems of coastal California. Soil Biol. Biochem. 34, 1599-1611. doi:10.1016/S0038-0717(02)00144-X

Treseder, K.K., Kivlin, S.N. and Hawkes, C.V., 2011. Evolutionary trade-offs among decomposers determine responses to nitrogen enrichment. Ecology Letters, 14(9), pp.933-938.

Wang, Y., Zhang, X., Huang, C., 2009. Spatial variability of soil total nitrogen and soil total phosphorus under different land uses in a small watershed on the Loess Plateau, China. Geoderma 150, 141-149. doi:10.1016/j.geoderma.2009.01.021

Wang, K., Zhang, C., Li, W., 2013. Predictive mapping of soil total nitrogen at a regional scale: A comparison between geographically weighted regression and cokriging. Appl. Geogr. 42, 73-85. doi:10.1016/j.apgeog.2013.04.002

Webster, R. and Oliver, M.A., 2007. Geostatistics for environmental scientists. John Wiley \& Sons.

Webster, R., 1985. Quantitative Spatial Analysis of Soil in the Field, in: Stewart, B.A. (Ed.), Advances in Soil Science. 
Springer New York, New York, NY, pp. 1-70. doi:10.1007/978-1-4612-5090-6_1

Yang, Q., Luo, W., Jiang, Z., Li, W. and Yuan, D., 2016. Improve the prediction of soil bulk density by cokriging with predicted soil water content as auxiliary variable. Journal of soils and sediments, 16(1), pp.77-84.

Zhao, X., Wu, P., Gao, X. and Persaud, N.I.R.M.A.L.A., 2015. Soil quality indicators in relation to land use and topography in a small catchment on the Loess Plateau of China. Land Degradation \& Development, 26(1), pp.54-61. 


\section{Figure captions}

Figure 1. Nested cyclic sampling design. The sampling intervals were every 10,35 , 85 , and $100 \mathrm{~m}$ for the west-to-east direction and every $10,35,85,95,120$, and $170 \mathrm{~m}$ for the north-tosouth direction ( $\mathrm{n}=36$; main panel). A $0.5,2,4.5 \mathrm{~m}$ cycle was applied in both directions for the smaller scale nest $(\mathrm{n}=20)$ as showed in the inset. There are also two additional sampling points (highlighted in green) that were strategically located in the field plots to increase the sampling efficiency.

Figure 2. Correlation network based on Spearman correlation coefficients among soil properties and topography variables in native grassland (NG) and irrigated cultivated land (IC). The black lines indicate positive correlations; the red lines indicate negative correlations. The thickness of the line shows the strength of the correlation. Only significant correlations with $r$ $>0.3$ are shown. Also, correlations between variables with high co-linearity (dependency) were not shown. The abbreviations for the variables are translated as follows: BD (bulk density), SatW (saturated volumetric water content), FC (field capacity water content), PAW (plant available water), ResW (residual water content), Sidx (S-index), Ks (saturated hydraulic conductivity), $\mathrm{K}$ (hydraulic conductivity at $-10 \mathrm{kPa}$ water potential), SOC (soil organic carbon) concentration, STN (soil total nitrogen) concentration, C.N (carbon-to-nitrogen ratio), MBC (microbial biomass carbon) concentration, F.B (fungal-to-bacteria ratio), Elev (terrain elevation), Curv (curvature), Aspt (aspect), Hill (hill shade), DTW (depth-to-water table).

Figure 3. Relationship between observed and predicted data of plant available water (PAW), soil organic carbon (SOC), and microbial biomass carbon (MBC) using cross-validation for ordinary kriging $(\mathrm{OK})$ and cokriging (coK) methods in native grassland $(\mathrm{NG})$ and irrigated cultivated land (IC). The cross-validation panels display both the 1:1 agreement line (dotted line) and the least-squared linear regression (continuous line).

Figure 4. Spatial distributions of soil organic carbon concentration (SOC; $\% \mathrm{~m} / \mathrm{m}$ ) by ordinary kriging $(\mathrm{OK})$ and cokriging (coK) methods in native grassland $(\mathrm{NG})$ and irrigated cultivated land (IC) using a nested cyclic sampling design. A LiDAR-derived depth-to-water table (DTW) was used as the covariate for the coK method.

Figure 5. Generalized visualization of the uncertainty prediction [standard deviation (SD)] for soil organic carbon (SOC; \% m/m) using ordinary kriging $(\mathrm{OK})$ and cokriging $(\mathrm{coK})$ methods in native grassland (NG) and irrigated cultivated land (IC). The inverse distance weighting (IDW) interpolation were used. The green dots are the 58 measured field locations. 
Tables

Table 1. Descriptive statistics of soil properties at native grassland (NG) and irrigated cultivated land (IC).

\begin{tabular}{|c|c|c|c|c|c|c|c|c|}
\hline Attributes & Sites & Mean & Median & Min & Max & Kurtosis & Skewness & SD \\
\hline \multirow{2}{*}{$\begin{array}{l}\text { Bulk density } \\
\left(\mathrm{g} \mathrm{cm}^{-3}\right)\end{array}$} & NG & $1.44 a$ & 1.44 & 1.14 & 1.63 & -0.30 & -0.41 & 0.11 \\
\hline & IC & $1.43 a$ & 1.43 & 1.09 & 1.65 & -0.40 & -0.39 & 0.14 \\
\hline \multirow{2}{*}{$\begin{array}{l}\text { Porosity } \\
\left(\mathrm{m}^{3} \mathrm{~m}^{-3}\right)\end{array}$} & NG & $0.455 a$ & 0.46 & 0.38 & 0.57 & -0.24 & 0.42 & 0.042 \\
\hline & IC & $0.460 a$ & 0.46 & 0.38 & 0.59 & -0.37 & 0.34 & 0.051 \\
\hline \multirow{2}{*}{$\begin{array}{l}\text { Sat. WC } \\
\left(\mathrm{m}^{3} \mathrm{~m}^{-3}\right)\end{array}$} & NG & $0.474 a$ & 0.47 & 0.34 & 0.57 & 1.81 & -0.50 & 0.041 \\
\hline & IC & $0.422 b$ & 0.43 & 0.29 & 0.56 & -0.20 & -0.20 & 0.058 \\
\hline \multirow{2}{*}{$\begin{array}{l}\mathrm{OFC} \\
\left(\mathrm{m}^{3} \mathrm{~m}^{-3}\right)\end{array}$} & NG & $0.118 b$ & 0.11 & 0.08 & 0.37 & 29.85 & 4.82 & 0.039 \\
\hline & IC & $0.154 a$ & 0.14 & 0.07 & 0.36 & 3.89 & 1.63 & 0.051 \\
\hline \multirow{2}{*}{$\begin{array}{l}\text { OPWP } \\
\left(\mathrm{m}^{3} \mathrm{~m}^{-3}\right)\end{array}$} & NG & $0.094 a$ & 0.10 & 0.00 & 0.16 & 5.18 & -1.07 & 0.023 \\
\hline & IC & $0.085 a$ & 0.08 & 0.01 & 0.17 & 0.04 & 0.57 & 0.034 \\
\hline \multirow{2}{*}{$\begin{array}{l}\text { PAW } \\
\left(\mathrm{m}^{3} \mathrm{~m}^{-3}\right)\end{array}$} & NG & $0.024 b$ & 0.01 & 0.00 & 0.21 & 12.09 & 3.08 & 0.035 \\
\hline & IC & $0.069 a$ & 0.05 & 0.01 & 0.27 & 1.95 & 1.25 & 0.053 \\
\hline \multirow{2}{*}{$\begin{array}{l}\text { Macroporosity } \\
\left(\mathrm{m}^{3} \mathrm{~m}^{-3}\right)\end{array}$} & NG & $0.355 a$ & 0.36 & 0.20 & 0.44 & 3.78 & -1.36 & 0.044 \\
\hline & IC & $0.268 b$ & 0.27 & 0.14 & 0.45 & 2.59 & 0.20 & 0.075 \\
\hline \multirow{2}{*}{$\begin{array}{l}\alpha \\
\left(\mathrm{hPa}^{-1}\right)\end{array}$} & NG & $0.020 \mathrm{~b}$ & 0.02 & 0.01 & 0.02 & 2.81 & 1.29 & 0.002 \\
\hline & IC & $0.024 a$ & 0.02 & 0.01 & 0.07 & 6.17 & 1.98 & 0.011 \\
\hline \multirow[t]{2}{*}{$\mathrm{n}$} & NG & $3.04 a$ & 3.06 & 1.22 & 4.72 & -0.22 & 0.08 & 0.77 \\
\hline & IC & $1.97 b$ & 1.97 & 1.24 & 3.16 & -0.54 & 0.37 & 0.48 \\
\hline \multirow{2}{*}{$\begin{array}{l}\Theta r \\
\left(\mathrm{~m}^{3} \mathrm{~m}^{-3}\right)\end{array}$} & NG & $0.091 a$ & 0.10 & 0.00 & 0.14 & 5.12 & -1.90 & 0.025 \\
\hline & IC & $0.072 b$ & 0.07 & 0.00 & 0.17 & -0.77 & 0.20 & 0.046 \\
\hline \multirow{2}{*}{$\begin{array}{l}\Theta \mathrm{s} \\
\left(\mathrm{m}^{3} \mathrm{~m}^{-3}\right)\end{array}$} & NG & $0.468 a$ & 0.47 & 0.34 & 0.56 & 1.62 & -0.62 & 0.041 \\
\hline & IC & $0.427 b$ & 0.44 & 0.30 & 0.53 & -0.29 & -0.30 & 0.053 \\
\hline \multirow[t]{2}{*}{ S-index } & NG & $0.106 a$ & 0.106 & 0.031 & 0.197 & 0.82 & 0.37 & 0.031 \\
\hline & IC & $0.055 b$ & 0.054 & 0.023 & 0.099 & -0.84 & 0.26 & 0.019 \\
\hline \multirow{2}{*}{$\begin{array}{l}\mathrm{Ks} \\
\left(\mathrm{cm} \mathrm{d}^{-1}\right)\end{array}$} & NG & $6.70 a$ & 3.68 & 0.46 & 52.20 & 13.81 & 3.36 & 8.75 \\
\hline & IC & $8.36 a$ & 2.39 & 0.30 & 120.20 & 24.92 & 4.64 & 18.60 \\
\hline \multirow{2}{*}{$\begin{array}{l}\text { Unsat. K } \\
\left(\mathrm{cm} \mathrm{d}^{-1}\right)\end{array}$} & NG & $0.18 a$ & 0.19 & 0.05 & 0.35 & 0.29 & 0.14 & 0.06 \\
\hline & IC & $0.08 b$ & 0.03 & 0.00 & 0.40 & 2.50 & 1.85 & 0.10 \\
\hline \multirow{2}{*}{$\begin{array}{l}\text { SOC concentration } \\
(\% \mathrm{~m} / \mathrm{m})\end{array}$} & NG & $1.05 a$ & 0.97 & 0.66 & 3.13 & 19.42 & 3.75 & 0.36 \\
\hline & IC & $1.09 a$ & 1.03 & 0.70 & 2.65 & 10.11 & 2.56 & 0.32 \\
\hline \multirow{4}{*}{$\begin{array}{l}\text { SOC density } \\
\left(\mathrm{g} \mathrm{m}^{-2} \text { soil }\right) \\
\text { STN } \\
(\% \mathrm{~m} / \mathrm{m})\end{array}$} & NG & $748 a$ & 698 & 497 & 1878 & 12.17 & 2.94 & 220 \\
\hline & IC & $779 a$ & 737 & 473 & 1961 & 15.21 & 2.7 & 242 \\
\hline & NG & $0.09 b$ & 0.08 & 0.05 & 0.28 & 9.68 & 2.51 & 0.04 \\
\hline & IC & $0.11 a$ & 0.10 & 0.06 & 0.24 & 7.92 & 2.13 & 0.03 \\
\hline \multirow[t]{2}{*}{$\mathrm{C} / \mathrm{N}$} & NG & $11.47 a$ & 11.85 & 9.17 & 14.20 & -1.18 & 0.05 & 1.36 \\
\hline & IC & $10.15 b$ & 9.91 & 8.18 & 13.50 & 0.90 & 1.10 & 1.22 \\
\hline \multirow[t]{2}{*}{$\mathrm{pH}$} & NG & $5.97 a$ & 5.94 & 5.08 & 7.42 & 3.23 & 0.89 & 0.37 \\
\hline & IC & $6.03 a$ & 6.02 & 5.18 & 6.86 & -0.38 & -0.17 & 0.40 \\
\hline & NG & $601 b$ & 527 & 178 & 1223 & 0.91 & 1.01 & 212 \\
\hline (nmol PLFA g ${ }^{-1}$ soil) & IC & $812 a$ & 621 & 268 & 2388 & 2.05 & 1.49 & 481 \\
\hline Elevation & NG & 722.0 & 721.9 & 720.6 & 723.2 & -0.88 & -0.04 & 0.5 \\
\hline$(\mathrm{m})$ & IC & 723.1 & 723.1 & 722.5 & 724.0 & -0.19 & 0.20 & 0.3 \\
\hline Curvature $\left(\mathrm{m}^{-1}\right)$ & NG & 0.01 & 0.00 & -14.0 & 31.75 & 13.52 & 1.24 & 2.54 \\
\hline & IC & 0.01 & 0.00 & -6.5 & 8.75 & 0.61 & 0.16 & 1.87 \\
\hline Slope $\left({ }^{\circ}\right)$ & NG & 2 & 1 & 0 & 8 & 3.66 & 1.71 & 1.1 \\
\hline & IC & 1 & 1 & 0 & 4 & 3.71 & 1.54 & 0.6 \\
\hline Aspect ( $\left.{ }^{\circ}\right)$ & NG & 155 & 131 & 0 & 360 & -1.04 & 0.41 & 100 \\
\hline & IC & 177 & 167 & 0 & 360 & -1.14 & 0.12 & 100 \\
\hline Hill shade $\left({ }^{\circ}\right)$ & NG & 179 & 179 & 161 & 194 & 1.66 & -0.34 & 4 \\
\hline & IC & 180 & 179 & 172 & 191 & 1.22 & 0.20 & 2 \\
\hline DTW & NG & 1.03 & 1.02 & 0.00 & 2.36 & -0.54 & 0.12 & 0.46 \\
\hline (m) & IC & 0.36 & 0.33 & 0.00 & 1.36 & 1.23 & 1.03 & 0.24 \\
\hline
\end{tabular}

Notes: Mean values between the land-use systems followed by a different letter are significantly different at $P<0.05$. NG: native grassland; IC; irrigated cultivated land; SD: standard deviation; $\theta \mathrm{FC}$ : field capacity water content; $\theta \mathrm{PWP}$ : permanent wilting point water content; PAW: plant available water; $\theta$ s: saturated volumetric water content; $\theta$ r: residual water content; $n$ : a shape parameter related to the curve smoothness; $\alpha$ : a negative inverse of the air-entry potential; S-index: the slope at the inflection point; Ks: saturated hydraulic conductivity; Unsat. K: hydraulic 
conductivity at $10 \mathrm{kPa}$; SOC: soil organic carbon; STN: soil total nitrogen; C/N: carbon to nitrogen ratio; MBC: microbial biomass carbon; DTW: depth to water. Number of samples (N) for soil properties is 58 per site, while $\mathrm{N}$ for terrain covariates is 7162 in the NG site and 6194 in the IC site. 
Table 2. Distinctive phospholipid fatty acid (PLFA) indicator species analysis associated with either the native grassland (NG) or the irrigated cultivated land (IC). Each value represents the mean indicator, with standard deviation in parentheses. The highest indicator value is in bold. Only PLFAs that were found to be significantly different among groups are presented.

\begin{tabular}{llcccc}
\hline \multirow{2}{*}{ PLFA } & \multirow{2}{*}{ Taxa biomarker } & \multicolumn{2}{c}{ Indicator Value } & \multicolumn{2}{c}{ Monte Carlo } \\
& & Mean & NG & IC & $P<0.05$ \\
\hline $14: 00$ & Bacteria in general & $41.8(2.65)$ & $\mathbf{5 3}$ & 26 & 0.0012 \\
$15: 1 \mathrm{i}$ & Gram - & $41.8(2.62)$ & $\mathbf{5 0}$ & 28 & 0.0044 \\
$17: 1 \mathrm{a}$ & Gram - & $15.5(2.86)$ & $\mathbf{3 1}$ & 2 & $<0.001$ \\
$17: 1 \omega 8 \mathrm{c}$ & Gram - & $50.4(0.84)$ & $\mathbf{5 4}$ & 45 & $<0.001$ \\
$17: 010$ methyl & Actinobacteria (Gram +$)$ & $49.7(1.31)$ & $\mathbf{5 3}$ & 43 & $<0.001$ \\
$16: 12 \mathrm{OH}$ & Anaerobic bacteria & $50.3(1.11)$ & $\mathbf{5 2}$ & 46 & 0.0226 \\
\hline
\end{tabular}


Table 3. Variographic (semivariogram and cross-semivariogram) models, fitting statistical indicators, and resulting validation parameters as a function of geostatistical approaches in both native grassland (NG) and irrigated cultivated land (IC).

\begin{tabular}{|c|c|c|c|c|c|c|c|c|c|c|c|}
\hline \multirow{2}{*}{ Attributes } & \multirow{2}{*}{$\begin{array}{l}\text { Prediction } \\
\text { Method }\end{array}$} & \multicolumn{6}{|c|}{ Variography } & \multicolumn{4}{|c|}{ Validation Parameters } \\
\hline & & Model & $\begin{array}{c}\text { Residual } \\
\text { SS }\end{array}$ & $\mathrm{r}^{2}$ & $\begin{array}{l}\text { Autocorrelation } \\
\text { Range }(\mathrm{m})\end{array}$ & Sill & $\begin{array}{c}\mathrm{C} 0 /(\mathrm{C} 0+\mathrm{C}) \\
(\%)\end{array}$ & NSE & SE predict & MPE & RMSPE \\
\hline \multicolumn{12}{|l|}{ NG } \\
\hline \multirow[t]{2}{*}{ PAW } & OK & G & 116.0 & 0.70 & 50 & 19.16 & 29.4 & 0.04 & 1.57 & -0.14 & 3.56 \\
\hline & $\mathrm{coK}$ & G & 1.43 & 0.63 & 90 & -1.662 & 18.0 & 0.85 & 0.97 & -0.02 & 1.53 \\
\hline \multirow[t]{2}{*}{ SOC } & OK & G & 0.03 & 0.43 & 47 & 0.164 & 16.0 & 0.06 & 0.15 & -0.01 & 0.35 \\
\hline & $\mathrm{coK}$ & G & $2.4 \times 10^{-3}$ & 0.73 & 99 & -0.076 & 9.3 & 0.92 & 0.08 & -0.01 & 0.12 \\
\hline \multirow[t]{2}{*}{$\mathrm{MBC}$} & OK & G & $5.4 \times 10^{8}$ & 0.70 & 99 & 50760 & 41.0 & 0.11 & 94.97 & -8.41 & 202 \\
\hline & $\mathrm{coK}$ & G & 673.0 & 0.91 & 113 & -73.20 & 2.2 & 0.74 & 63.47 & -4.37 & 121 \\
\hline \multicolumn{12}{|l|}{ IC } \\
\hline \multirow[t]{2}{*}{ PAW } & OK & G & 497.0 & 0.63 & 64 & 28.96 & 13.9 & 0.40 & 2.80 & -0.40 & 4.12 \\
\hline & $\operatorname{coK}$ & G & 0.82 & 0.72 & 90 & -1.140 & 0.1 & 0.94 & 1.12 & -0.08 & 1.33 \\
\hline \multirow[t]{2}{*}{ SOC } & OK & S & 0.05 & 0.31 & 63 & 0.117 & 0.1 & 0.74 & 0.14 & 0.00 & 0.16 \\
\hline & $\mathrm{coK}$ & G & $1.05 \times 10^{-3}$ & 0.20 & 70 & 0.014 & 10.1 & 0.76 & 0.18 & -0.01 & 0.18 \\
\hline \multirow[t]{2}{*}{ MBC } & OK & G & $1.9 \times 10^{11}$ & 0.07 & 35 & 218800 & 17.7 & 0.53 & 235.00 & 42.49 & 330 \\
\hline & coK & $\mathrm{G}$ & 1042.0 & 0.77 & 80 & -47.85 & 0.2 & 0.87 & 141.74 & 5.88 & 184 \\
\hline
\end{tabular}

Notes: Units for all presented variables are as detailed in Table $1 . \mathrm{C} 0 /(\mathrm{C} 0+\mathrm{C})$ : nugget to sill ratio; G: gaussian; S: spherical ; OK: ordinary kriging; coK: cokriging; PAW: plant avail 


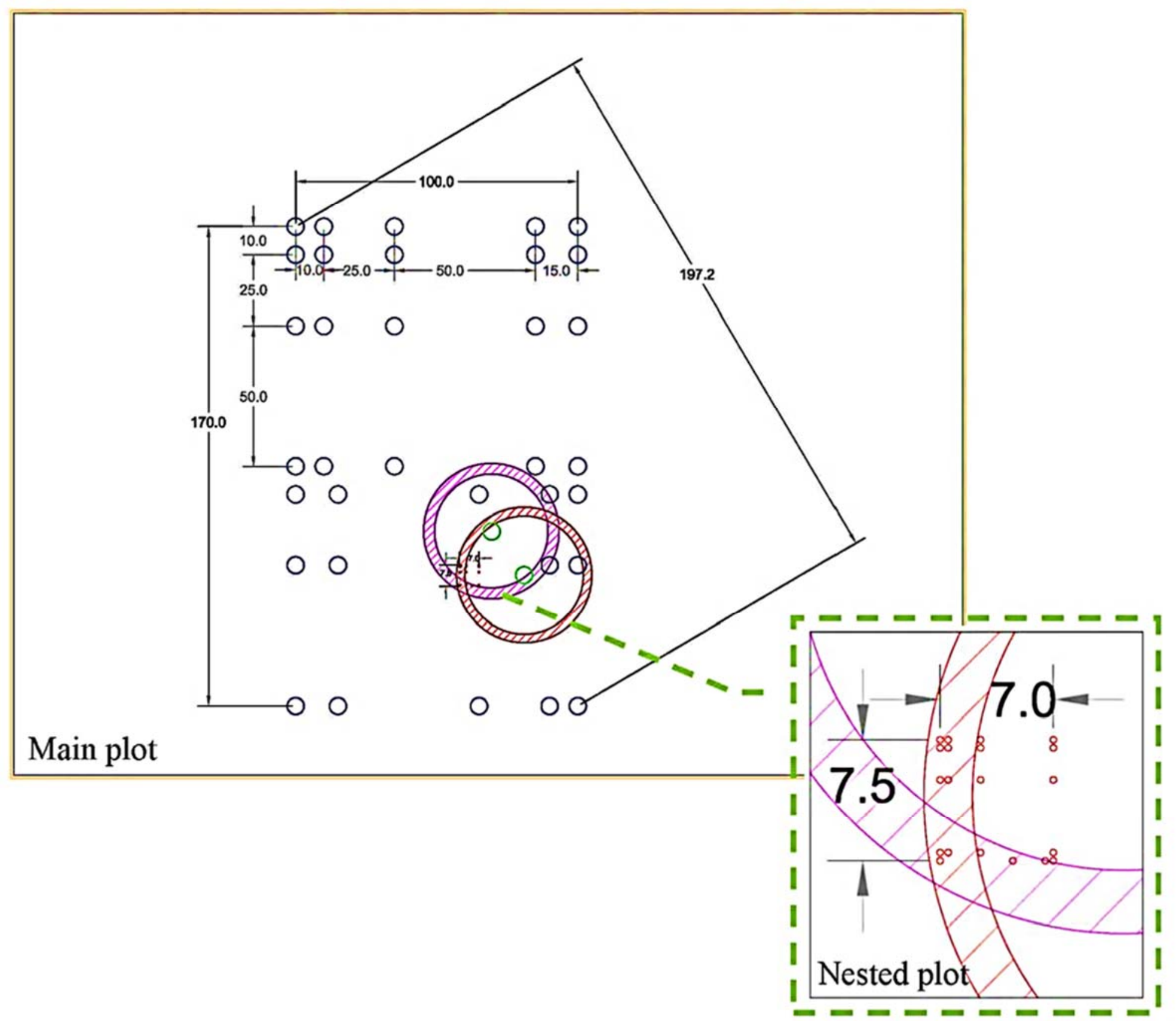

Figure 1. Nested cyclic sampling design. The sampling intervals were every $10,35,85$, and $100 \mathrm{~m}$ for the west-to-east direction and every $10,35,85,95,120$, and $170 \mathrm{~m}$ for the north-to-south direction ( $\mathrm{n}=36$; main panel). A $0.5,2,4.5 \mathrm{~m}$ cycle was applied in both directions for the smaller scale nest $(\mathrm{n}=20)$ as showed in the inset. There are also two additional sampling points (highlighted in green) that were strategically located in the field plots to increase the sampling efficiency. 


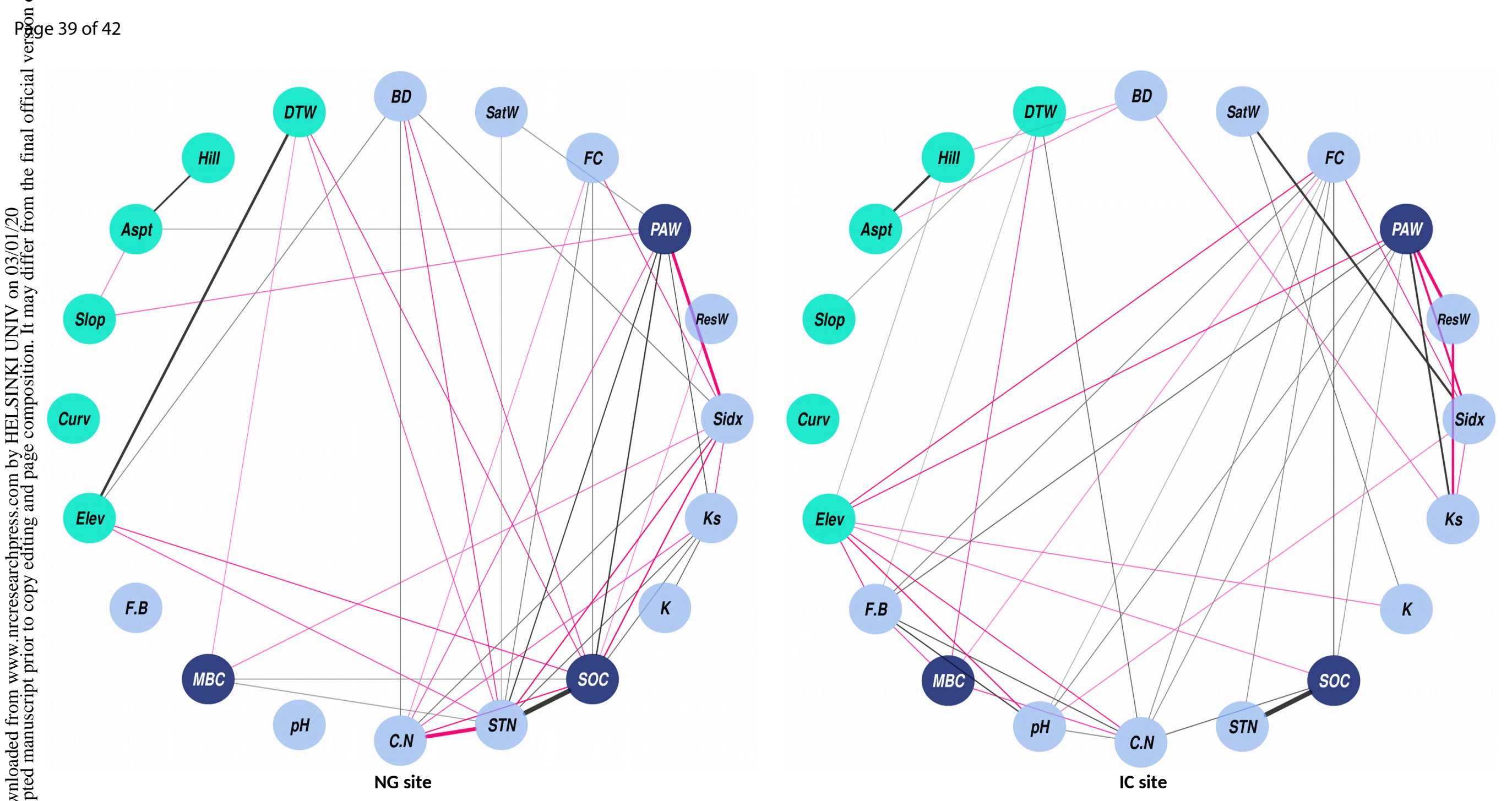

Figure 2. Correlation network based on Spearman correlation coefficients among soil properties and topography variables in native grassland (NG) and irrigated cultivated land (IC). The black lines indicate positive correlations; the red lines indicate negative correlations. The thickness of the line shows the strength of the correlation. Only significant correlations with $r>0.3$ are shown. Also, correlations between variables with high co-linearity (dependency) were not shown. The abbreviations for the variables are translated as follows: BD (bulk density), SatW (saturated volumetric water content), FC (field capacity water content), PAW (plant available water), ResW (residual water content), Sidx (Sindex), Ks (saturated hydraulic conductivity), $\mathrm{K}$ (hydraulic conductivity at $-10 \mathrm{kPa}$ water potential), SOC (soil organic carbon) concentration, STN (soil total nitrogen) concentration, C.N (carbon-to-nitrogen ratio), MBC (microbial biomass carbon) concentration, F.B (fungal-to-bacteria ratio), Elev (terrain elevation), Curv (curvature), Aspt (aspect), Hill (hill shade), DTW (depth-to-water table). 
PAW

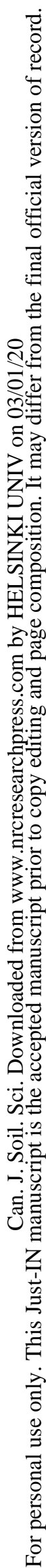

$\frac{1}{5}$
0
0

PAW

$\stackrel{\underline{N}}{\underline{n}}$
SOC
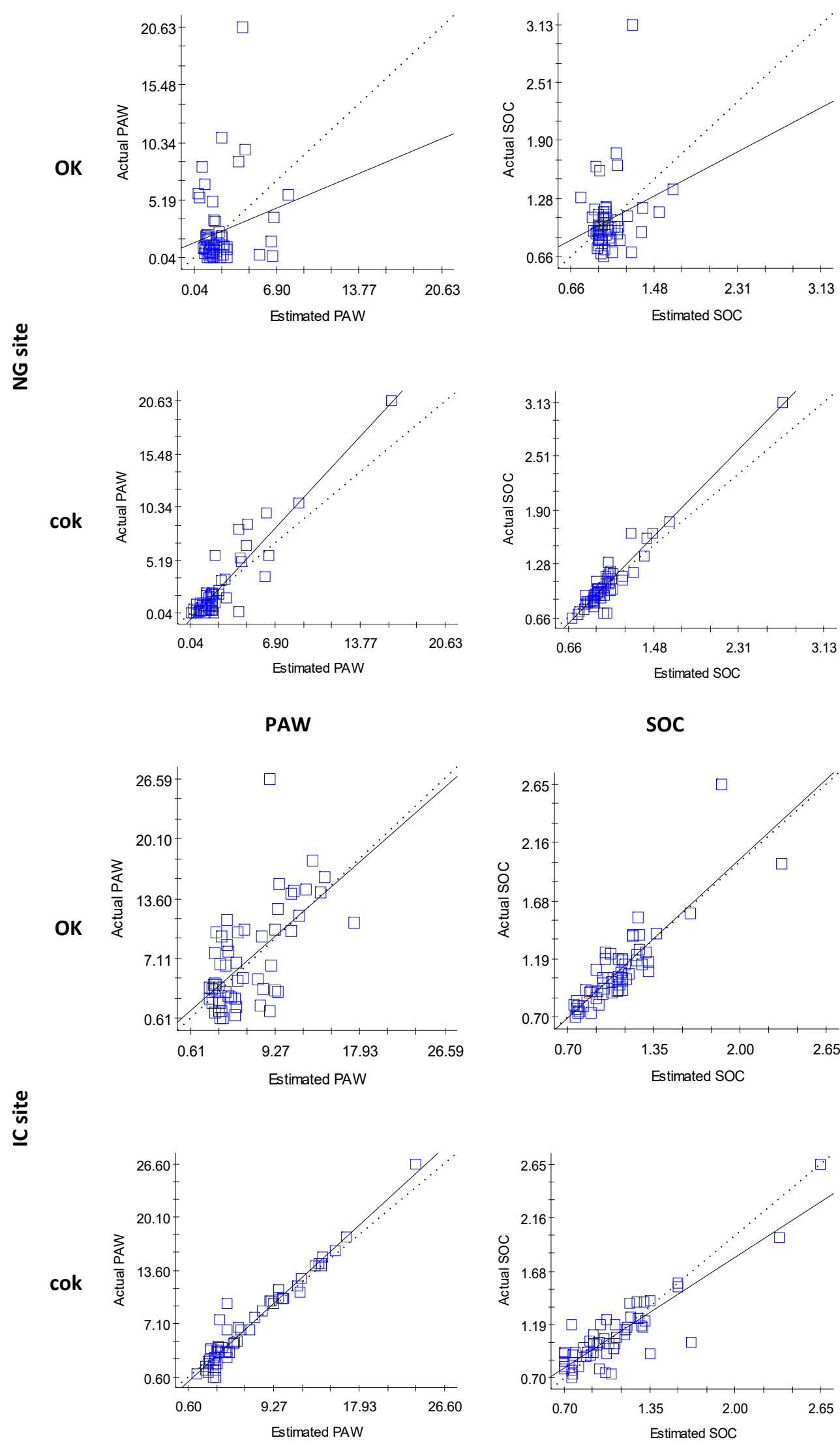

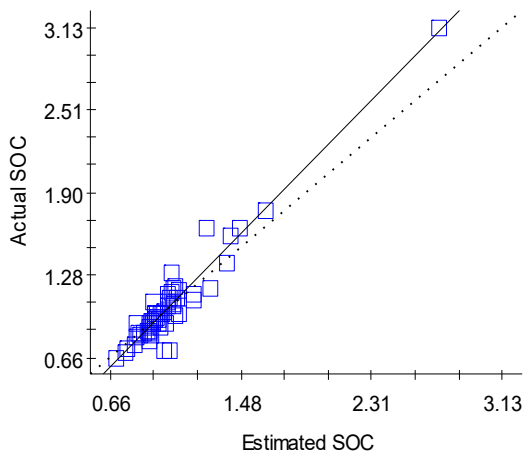

SOC
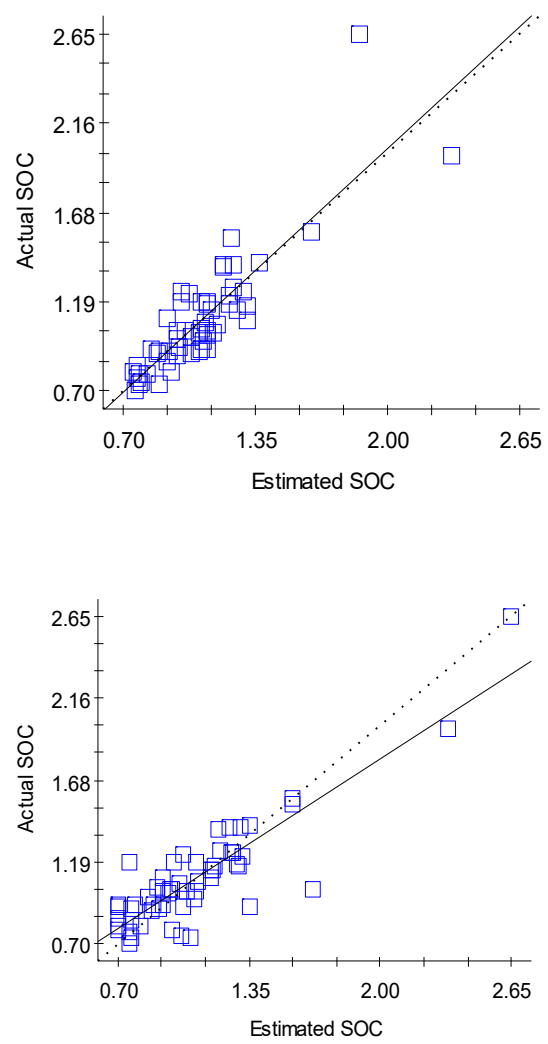

MBC
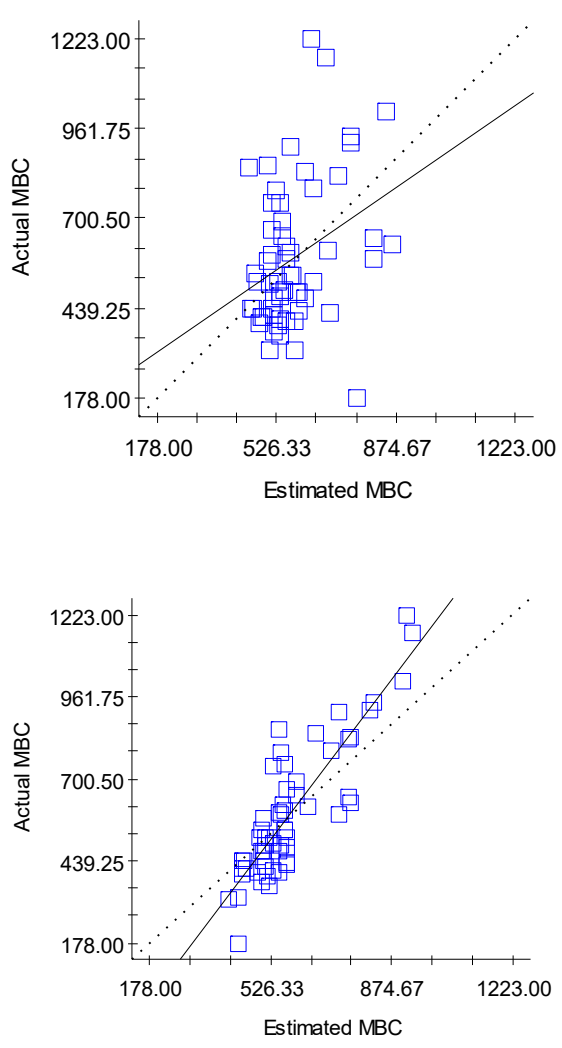

MBC
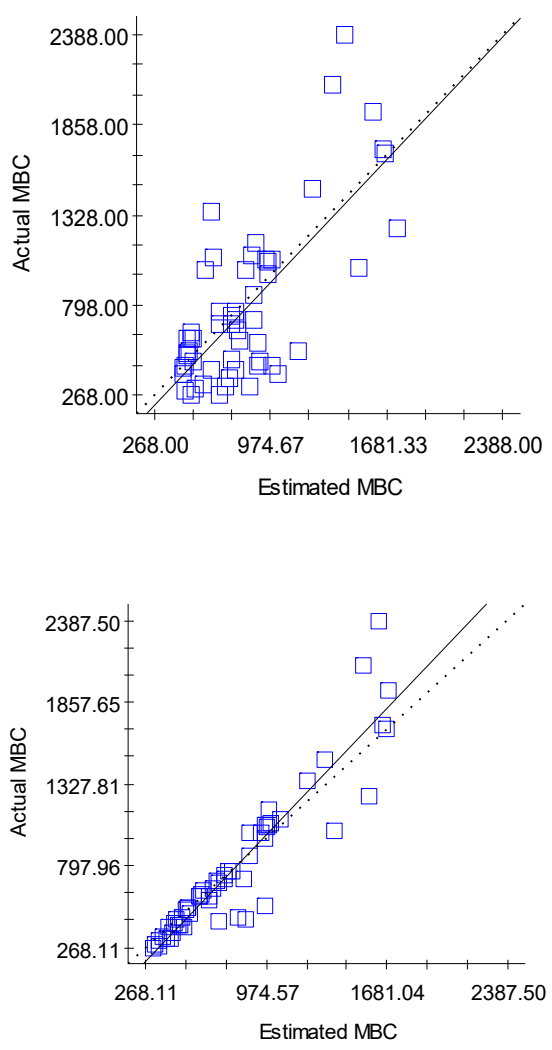

Figure 3. Relationship between observed and predicted data of plant available water (PAW), soil organic carbon (SOC), and microbial biomass carbon $(\mathrm{MBC})$ using cross-validation for ordinary kriging $(\mathrm{OK})$ and cokriging (coK) methods in native grassland (NG) and irrigated cultivated land (IC). The cross-validation panels display both the 1:1 agreement line (dotted line) and the least-squared linear regression (continuous line). 

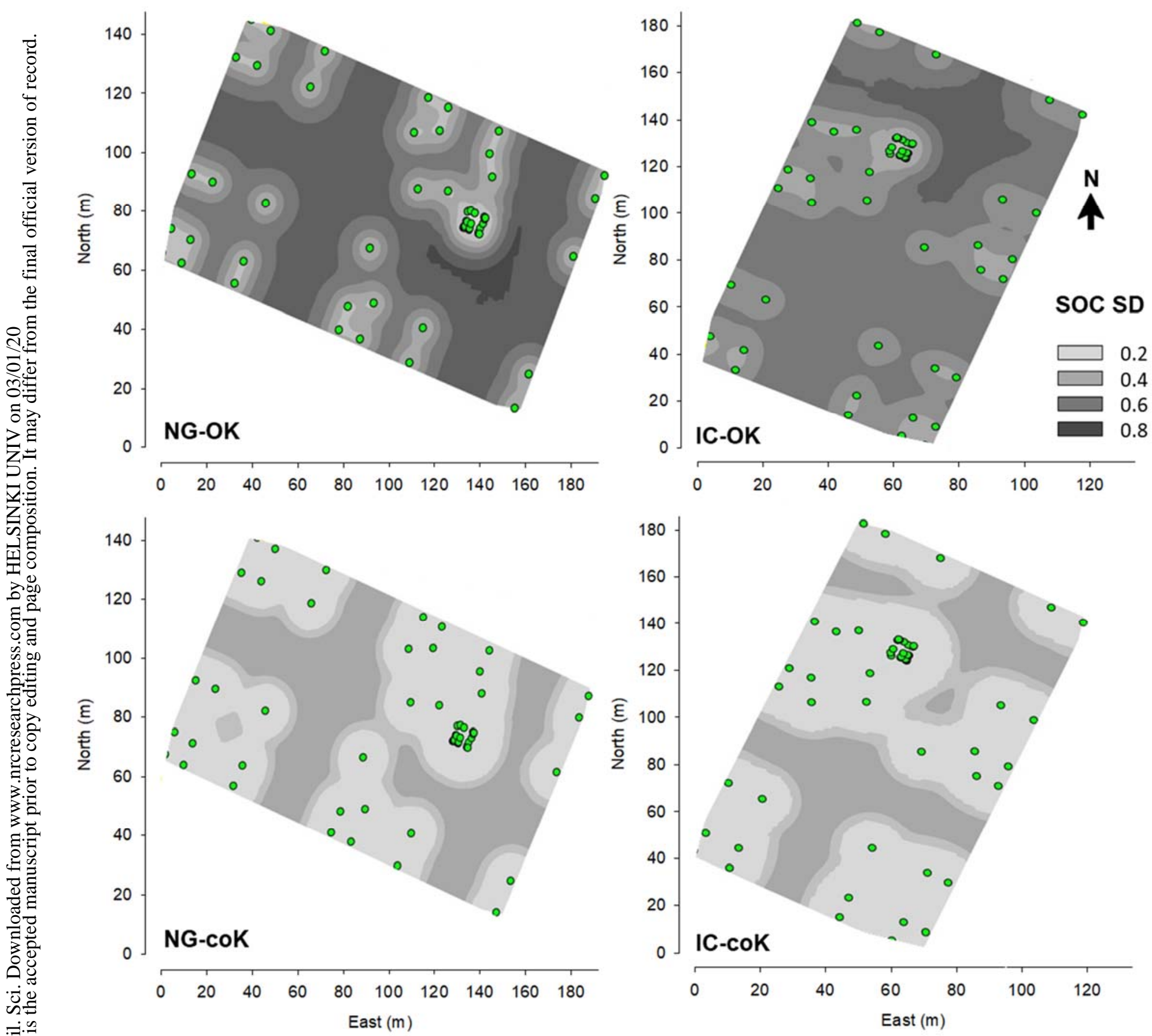

Figure 5. Generalized visualization of the uncertainty prediction [standard deviation (SD)] for soil organic carbon (SOC; \% $\mathrm{m} / \mathrm{m}$ ) using ordinary kriging (OK) and cokriging (coK) methods in native grassland (NG) and irrigated cultivated land (IC). The inverse distance weighting (IDW) interpolation were used. The green dots are the 58 measured field locations. 